\title{
Utilisation of bacteria as nitrogen resource by kelp-bed mussel Choromytilus meridionalis
}

\author{
L. J. Seiderer ${ }^{1}$, C. L. Davis ${ }^{2}$, F. T. Robb ${ }^{2}$ and R. C. Newell ${ }^{3}$ \\ ${ }^{1}$ Department of Zoology, ${ }^{2}$ Department of Microbiology, University of Cape Town, South Africa \\ ${ }^{3}$ Royal Society Senior Research Fellow, c/o Institute for Marine Environmental Research, Plymouth, United Kingdom
}

\begin{abstract}
The crystalline style of Choromytilus meridionalis Krauss contains a bacteriolytic enzyme capable of lysing the majority of free-living bacteria in the adjacent water column. Estimates of the carbon-to-nitrogen ratio (3.7:1) of free-living bacteria, and of the filtration capabilities of the mussels, indicate that bacteria could meet the nitrogen requirements of the mussels. The bacteriolytic agent in the style is subject to considerable adaptive changes in activity, correlated with water temperature. Water temperatures $<10^{\circ} \mathrm{C}$ are associated with induction of the bacteriolytic agent. During upwelling, cold water depleted in particulate matter but containing significant numbers of bacteria occurs commonly amongst the kelp beds. It is suggested that low water temperature (or an associated environmental parameter) results in stimulation of bacteriolysis. This in turn permits efficient utilisation by the mussel of free-living bacteria which compensate for the depletion of phytoplankton available in the water column.
\end{abstract}

\section{INTRODUCTION}

There have been many studies of the potential significance of bacteria in the nutrition of marine animals (recent reviews: Watson, 1978; Mann, 1982). Although some filter-feeding bivalves such as the bay scallop Argopecten irradians utilise phytoplankton rather than the microbial component of plant detritus (KirbySmith, 1976), many other filter-feeders including both bivalves (Sorokin, 1973) and sponges (Reiswig, 1971) may derive a major proportion of their diet from bacteria and associated sub-particulate material. A wide range of deposit-feeding organisms, especially those exploiting detrital food resources with high $\mathrm{C}: \mathrm{N}$ ratios such as occur near to saltmarshes and macroalgae, have also been shown to derive a significant proportion of their diet from the ingestion of the bacterial component of decomposing plant detritus. Such organisms include polychaetes (Tenore, 1977a, b), gastropods (Newell, 1965; Wetzel, 1976), amphipods (Fenchel, 1970), mysids (Foulds and Mann, 1978), prawns (Moriarty, 1976, 1977), holothurians (Yingst, 1976), and fish (Moriarty, 1976).

Some of these deposit-feeders may actively select smaller-sized particles from the deposits and thus enrich the bacterial component of their diet compared with non-selective deposit-feeders (review: Newell,
1979). Prieur (1981) showed, in addition, that the gut microflora may divide several times during passage through the gut of the mussel Mytilus edulis, so that the yield from bacteria could be considerably in excess of the standing stock or biomass of bacteria ingested with the diet. Complex interactions between gut microflora and detritus utilisation by the host have also been implicated in studies on the nutrition of Mysis sterolepis (Foulds and Mann, 1978) and Strongylocentrotus (Fong and Mann, 1980). More recently, Newell and Field (1983), in a study of carbon and nitrogen flux through kelp beds, estimated that utilisation of bacteria associated with detritus could contribute as much as $69 \%$ of the nitrogen requirements of the consumer community as a whole. Both the interactions of the gut microflora with the ingested detrital diet and the utilisation of free-living bacteria ingested with particulate debris are thus potentially implicated in the nutrition of detritivores.

There have, however, been very few investigations of the digestive enzymes actually involved in the utilisation of detritus and its associated microflora by invertebrates. Kristensen (1972) and Yingst (1976) have reviewed the evidence that comparatively few deposit-feeding invertebrates possess the necessary enzymes to digest the structural carbohydrates which make up the bulk of aged plant detrital material. 
However, Stuart (1982) and Stuart et al. (1982) have recently shown that the kelp-bed mussel Aulacomya ater is capable of absorption of sterilised kelp detritus with an efficiency of approximately $50 \%$. Again, Seiderer et al. (1982) have shown that 2 mussels, Choromytilus meridionalis and Perna perna, both possess the necessary style carbohydrases to digest plant detrital material. Furthermore, the rate of digestion by the style enzymes was linked to the gut passage time in such a way that the carbon requirements of the mussels could be met from a detrital diet alone.

Apart from the work of McHenery et al. (1979), and McHenery and Birkbeck $(1979,1982)$ there have been very few studies of the digestive enzymes which are required for the utilisation of the bacterial component of such detrital diets. McHenery et al. (1979) described the occurrence of a lysozyme-like enzyme in the bivalves Mytilus edulis, Modiolus modiolus, Chlamys opercularis and Mya arenaria and suggested that its primary role is in the utilisation of bacteria. McHenery and Birkbeck (1982) subsequently showed that the enzyme from $M$. edulis is a true $\mathrm{N}$-acetylmuramylhydrolase capable of degrading the cell walls of a variety of bacteria including Micrococcus luteus, Escherichia coli and Bacillus subtilis.

Clearly, the occurrence and activity of such lysozyme-like enzymes is of importance in estimating the significance of bacteria as a carbon, and above all, a nitrogen resource for consumer organisms which are exploiting detrital diets with a high $\mathrm{C}: \mathrm{N}$ ratio. The relative resistance of the resident gut microflora to such lysozyme-like enzymes compared with free-living bacteria ingested with the food may yield some insight into the role of free-living as opposed to resident gut microflora in the nutrition of the consumer. The following work was therefore undertaken to examine the occurrence and role of lysozyme-like enzymes in the utilisation of bacteria as a protein resource by the kelp-bed mussel Choromytilus meridionalis whose carbon balance on a detrital diet has already been established in previous publications (Seiderer and Newell, 1979; Seiderer et al., 1982).

\section{MATERIALS AND METHODS}

\section{Sampling and preparation of style extract}

Specimens of the black mussel Choromytilus meridionalis Krauss were collected from a rocky intertidal reef at Bloubergstrand, West Coast of South Africa, between Nov 1982 and Feb 1983 and transferred to the laboratory for immediate extraction of the crystalline style. The styles of 20 specimens were removed, rinsed and homogenised over ice with a glass tissue grinder in $12 \mathrm{ml} 20 \mathrm{mM}$ phosphate buffer $\mathrm{pH} 7.0$, containing $150 \mathrm{mM} \mathrm{NaCl}$ (see also Langton, 1977; Seiderer and Newell, 1979; Seiderer et al., 1982). All glassware had been sterilised immediately prior to use. The homogenate was centrifuged at $15,000 \times \mathrm{g}$ for $5 \mathrm{~min}$ and the supernatant diluted to $1.00 \mathrm{mg}$ protein $\mathrm{ml}^{-1}$ (Groves et al., 1968) with phosphate buffer before using in lysozyme and protease assays.

\section{Isolation and culture of bacterial strains}

In order to isolate water-column bacteria, samples of seawater were taken from Oudekraal, also on the West Coast of South Africa, and incubated in the laboratory at $10^{\circ} \mathrm{C}$ with $0.5 \mathrm{~g} \mathrm{l}^{-1}$ sterilised powdered kelp detritus. This had been prepared by grinding freezedried tips of the fronds of Laminaria pallida, sieving to obtain particles from 43 to $63 \mu \mathrm{m}$ diameter, followed by sterilisation for $24 \mathrm{~h}$ under a UV light (see also Stuart et al., 1981). Subsamples of $1 \mathrm{ml}$ were taken after $3 \mathrm{~d}$ of incubation and pipetted onto agar plates made of $1.5 \%$ agar in seawater growth medium. The liquid growth medium comprised three parts $0.45 \mu \mathrm{m}$ filtered seawater, one part glass-distilled water and $0.5 \% \mathrm{w} / \mathrm{v}$ peptone (Oxoid), $0.1 \% \mathrm{w} / \mathrm{v}$ yeast extract (Difco) and $0.01 \% \mathrm{w} / \mathrm{v}$ ferric phosphate (Mazure, 1977). Plates were then incubated at 25 to $30{ }^{\circ} \mathrm{C}$ for 24 to $48 \mathrm{~h}$. Twenty five strains were isolated and restreaked at least 5 times before being assigned to collections and stored on slants of seawater agar at $4{ }^{\circ} \mathrm{C}$.

Bacterial isolates were also prepared from the gut contents of Choromytilus meridionalis. The guts of 4 mussels were removed and the contents cultured on seawater-agar plates at $20{ }^{\circ} \mathrm{C}$ after treatment with $1 \%$ trypsin for $30 \mathrm{~min}$ at $30^{\circ} \mathrm{C}$. Cultures were also made from homogenised gut tissues and a total of 20 strains were isolated and stored on seawater agar at $4{ }^{\circ} \mathrm{C}$.

Each of the isolates in the collections was then incubated in an orbital shaker at $30^{\circ} \mathrm{C}$ for $10 \mathrm{~h}$ in $2 \mathrm{ml}$ seawater liquid growth medium. These were then reinoculated into $50 \mathrm{ml}$ growth medium and grown at $30^{\circ} \mathrm{C}$ for a further $12 \mathrm{~h}$ before being used for preparation of experimental agarose plates.

\section{Preparation and incubation of plates}

The activity of lysozyme-like enzymes on free-living bacteria and on bacteria isolated from the gut of Choromytilus meridionalis was assayed on $0.8 \%$ agarose plates containing heat-killed target bacteria (McHenery et al., 1979). The bacterial suspensions were centrifuged at $8,000 \times \mathrm{g}$ for $15 \mathrm{~min}$ and the 
pellets resuspended in $2 \mathrm{ml}$ sterile seawater. The suspensions were then adjusted with sterile seawater so that the final optical density in the agarose medium would be 0.122 at $600 \mathrm{nM}$, and added to $20 \mathrm{ml}$ agarose medium. The media were then heat-shocked at $65^{\circ} \mathrm{C}$ for 10 to $15 \mathrm{~min}$ to kill the bacteria, and poured into $8.4 \mathrm{~cm}$ diameter petri dishes. Wells of equal diameter were cut into each agarose plate to receive the enzyme extract.

Eight serial 10-fold dilutions of enzyme extract (p. 110) were prepared and aliquots of $10 \mu \mathrm{l}$ of each of the dilutions were placed individually into the wells and incubated at $20^{\circ} \mathrm{C}$ for $45 \mathrm{~h}$. Intact bacteria were stained by addition of $5 \mathrm{ml}$ of $0.12 \%$ crystal violet to each plate. After $2 \mathrm{~h}$, the plates were rinsed with distilled water and the diameter of the clear zones of lysis was measured. From the number of bacteria per unit surface area of plates, the area of the clear zone could be expressed both as number of bacteria lysed per $45 \mathrm{~h}$ of incubation at $20^{\circ} \mathrm{C}$, and its equivalent in bacterial protein. The equations for the regressions were: bacterial number lysed $\left(\times 10^{5}\right) \hat{Y}=-0.92+0.11 X$; bacterial protein $(\mu \mathrm{g}) \hat{\mathrm{Y}}=-0.36+0.05 \mathrm{X}$ (where $\mathrm{X}=$ zone diameter in $\mathrm{mm}$ ).

\section{Interference contrast micrographs}

An isolated water column pseudomonad was cultured in seawater growth medium (p. 110) and rinsed in $5 \mathrm{ml} 10 \mathrm{mM}$ ammonium acetate buffer $\mathrm{pH} 7.0$ to remove salts. To the experimental bacteria, a 1-in-5 volume of style extract which was known to have bacteriolytic activity was added. In the control tube the style extract was replaced with phosphate buffer, pH 7.0. Micrographs were taken after 30 min using a Zeiss microscope equipped with interference contrast optics.

\section{CHN-analysis}

Particulate organic carbon and nitrogen measurements were made on seawater which had been initially filtered through a $200 \mu \mathrm{m}$ mesh net to remove larger particulate material. A measured volume of 100 to $1,000 \mathrm{ml}$, depending on the particulate load, was filtered under a vacuum of $<12 \mathrm{~cm} \mathrm{Hg}$ through $25 \mathrm{~mm}$ Whatman GF/C glass fibre filters which had been preashed at $400^{\circ} \mathrm{C}$ for $6 \mathrm{~h}$. The filters were stored at $-20^{\circ} \mathrm{C}$ and then ovendried at $55^{\circ} \mathrm{C}$ prior to analysis with a Heraeus model CHN-Mikro Universal combustion analyser calibrated with cyclohexanone (Monar, 1972).

Bacterial carbon and nitrogen measurements were made on five isolates of bacteria which had been cultured in both nutrient-rich (18 h incubation at $\left.30^{\circ} \mathrm{C}\right)$ and nutrient-poor $\left(6 \mathrm{~d}\right.$ incubation at $\left.15^{\circ} \mathrm{C}\right)$ media. The nutrient-rich medium consisted of liquid seawater broth, and the nutrient-poor medium of artificial seawater (Sieburth, 1979) to which $25 \mu \mathrm{g}$ atoms Nitrate $\mathrm{N} \mathrm{ml}^{-1}$ and $6.25 \mathrm{mg} \mathrm{Mannitol} \mathrm{l}^{-1}$ had been added. This nutrient level and incubation temperature is thought to approximate that found under upwelling conditions in the kelp bed. The cultured bacteria were harvested by centrifugation at $7,000 \times g$ for $10 \mathrm{~min}$, resuspended in ammonium acetate buffer $\mathrm{pH} 7.0$, and lyophilised to constant weight. These weighed samples were combusted in the Heraeus combustion analyser to obtain C:N ratios for locally isolated bacteria.

\section{RESULTS}

\section{Lysis of target bacteria}

The zones of lysis which formed the basic assay for lysozyme activity in extracts of the crystalline style from Choromytilus meridionalis are shown in Fig. 1. The assay for the activity of this factor is extremely well reproducible and sensitive, due to the use of crystal violet to enhance contrast of low levels of target bacteria. The bacterium used as the target organism throughout this study was isolated from the water column near the sampling site at Oudekraal and iden-

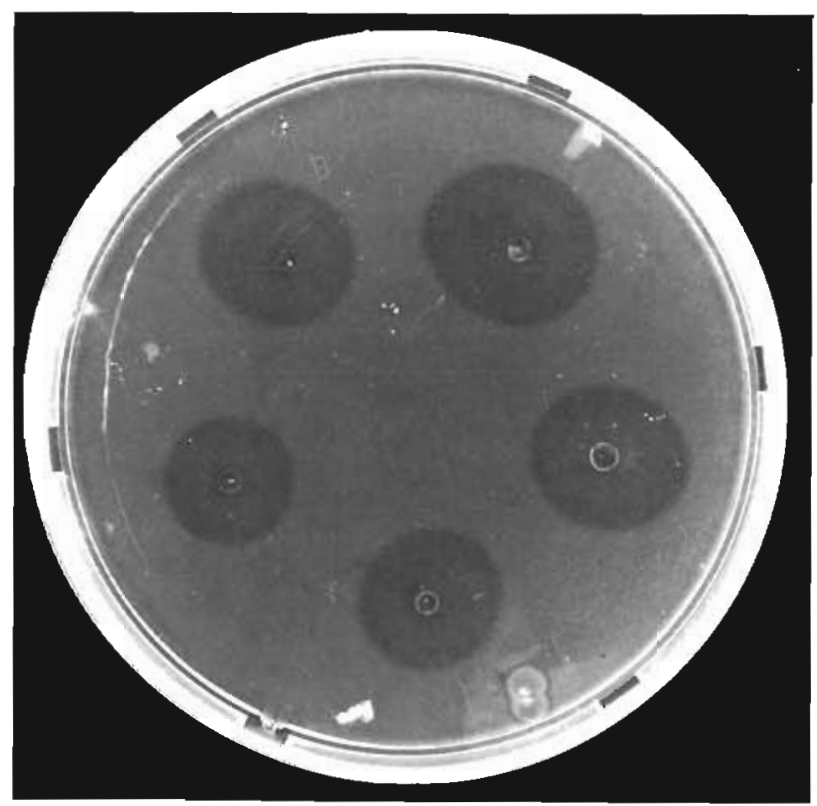

Fig. 1. Choromytilus meridionalis. Plate assay for lysozymelike activity in crystalline style extracts in which heat-killed target bacteria suspended in sea-water agarose are lysed by serial 1:10 dilutions of style extract 
tified as a pseudomonad. Several bacterial isolates from the water column displayed similar sensitivities, independent of bacterial genus; on average $57 \%$ of the water column bacteria were susceptible to lysis. Bacterial isolates from onshore sampling sites, in particular from the gut of $C$. meridionalis, displayed varying, and in some cases complete, resistance to the lytic activity in active style extracts (Muir et al., in prep.).

The lysozyme appears to induce breakdown of the outer membrane and cell walls, as shown in Fig. 2, and results in the liberation of the cell contents of the water column bacteria which are thus available for absorption by the mussel. The diameter of the zone of lysis, and hence the number of target bacteria lysed, can be calculated from the regression: bacterial number lysed $\left(\times 10^{5}\right)=-0.92+0.11 \times$. The equivalent protein liberated from bacterial breakdown is related to the diameter of the zone of lysis by the regression: bacterial protein $(\mu \mathrm{g})=-0.36+0.05 \mathrm{X}$ (where $\mathrm{X}=$ zone diameter in $\mathrm{mm}$; see also p. 111).

\section{Variations in bacteriolytic activity}

One of the striking features of bacteriolytic activity from the crystalline style of Choromytilus meridionalis is that it is very variable, reaching a minimum during periods of onshore wind with associated downwelling of phytoplankton-rich water which is commonly from 14 to $15^{\circ} \mathrm{C}$. Conversely, during offshore wind when cold upwelled water of approximately $9{ }^{\circ} \mathrm{C}$ impinges on the kelp bed, there is a considerable reduction in phytoplankton available for consumption by the filterfeeders (see Field et al., 1977, 1980, 1981). Turnover of style enzymes can take place within $18 \mathrm{~h}$ (Seiderer et al., 1982) and bursts of lytic activity were observed within $24 \mathrm{~h}$ of the onset of upwelling. These temporal variations in the activity of lysozyme-like enzymes in the style therefore appear to be actively induced by changes in environmental conditions during the upwelling-downwelling cycle

The relation between the bacteriolytic activity of crystalline style extracts and the temperature of the water during a complete upwelling-downwelling cycle in March, 1983, is shown in Fig. 3. There is evidently an inverse correlation between seawater temperature and the activity of lysozyme-like enzymes in the style, periods of upwelling and relatively low phytoplankton abundance being associated with high bacteriolytic activity by the style. The relation between bacteriolysis and water temperature is described by the following linear regression: cells lysed by $1 \mu l$ style

- Dr. E. A. S. Linley, Institute for Marine Environmental Research, Prospect Place, Plymouth PLI 3DH, UK
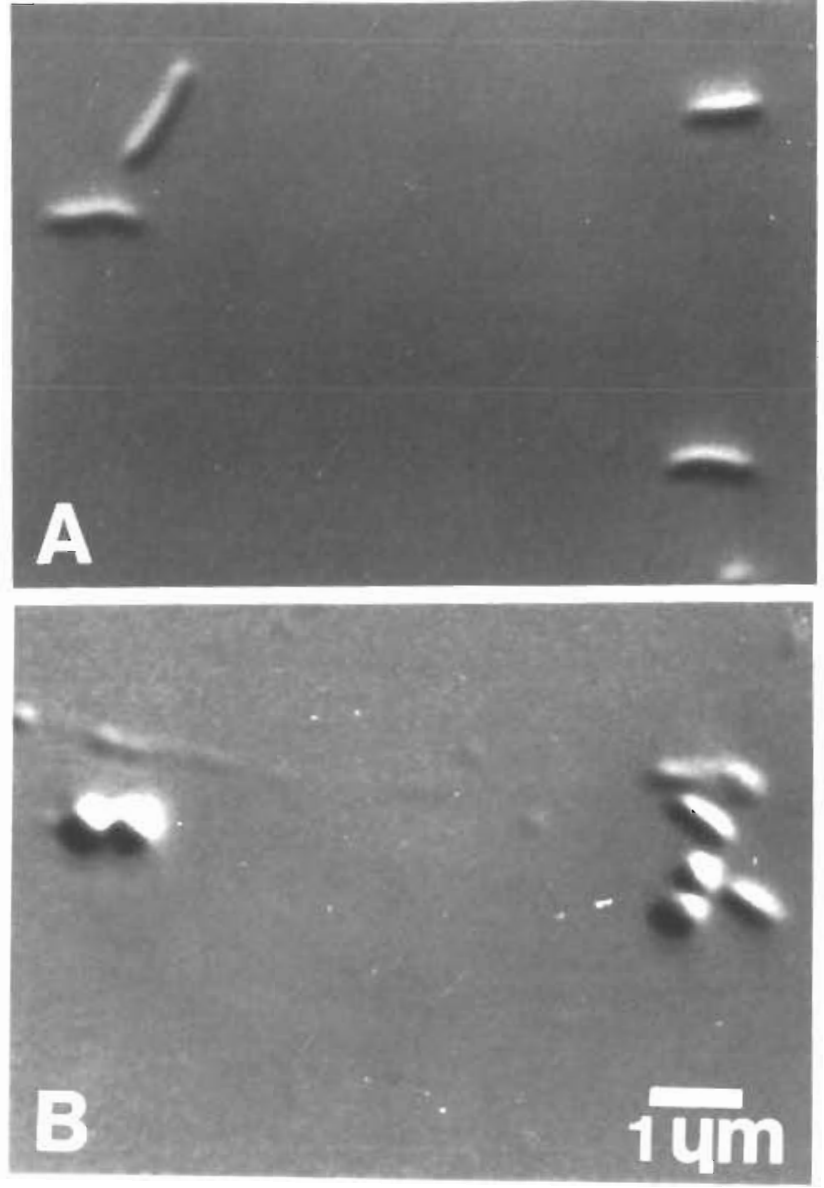

Fig. 2. Interference contrast micrographs showing an intact Pseudomonad (A) and the same Pseudomonad after $30 \mathrm{~min}$ exposure to a 1 -in-5 volume of style extract of Choromytilus meridionalis (B)

extract $\left(\times 10^{5}\right)=\mathrm{ke}^{-1.24 \mathrm{~T}}$, where $\mathrm{T}=$ seawater temperature ${ }^{\circ} \mathrm{C} ; \mathrm{k}=\mathrm{e}^{14.88}$ cells

Using direct microscopy, mean bacterial numbers were $4 \times 10^{5}$ cells $\mathrm{ml}^{-1}$ during upwelling and 2 to $3 \times 10^{6}$ cells $\mathrm{ml}^{-1}$ during downwelling conditions (Linley", pers. comm.). Table 1 shows C:N ratios of particulate material from macrophytes, phytoplankton and bacteria. From this it is clear that the bacteria which are likely to be lysed primarily during periods of upwelling of cold phytoplankton-poor water represent a relatively nitrogen-rich nutritional resource. Periods of downwelling of phytoplankton-rich water (Hutchings, 1981; Mann, 1982) are likely to be associated with a higher $C: N$ ratio in the potential food supply in the water column.

The extent to which these trophic resources could meet the carbon and nitrogen requirements of the consumer mussels can be calculated from the concentration of materials in the water column, coupled with some estimates of the consumer demands based on the carbon and nitrogen budgets for individual mussels. 


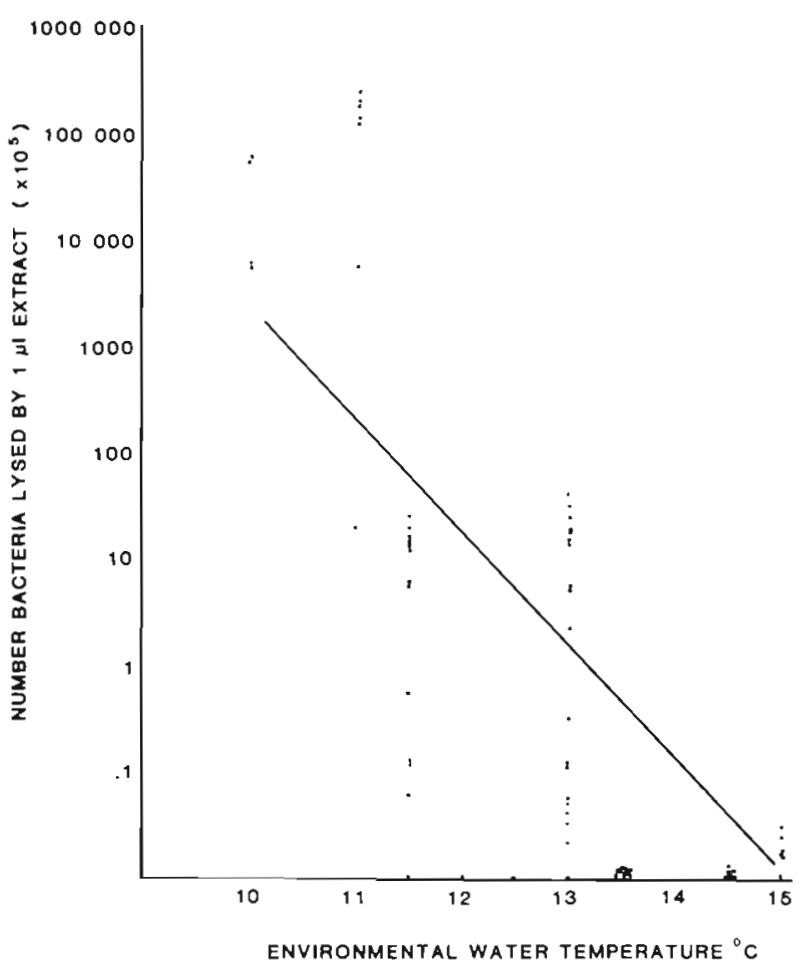

Fig. 3. Choromytilus meridionalis. Numbers of bacterial cells lysed by $1 \mathrm{ml}$ of crystalline style extract, plotted as a function of environmental sea-water temperature. Regression equation: cells lysed $=\mathrm{ke}^{-1.124 \mathrm{~T}}$, where $\mathrm{T}={ }^{\circ} \mathrm{C}$; cells lysed $=$ the number of cells lysed by $1 \mu \mathrm{l}$ style extract $\left(\times 10^{5}\right)$ and $\mathrm{k}=$ $\mathrm{e}^{14.88}$ cells

\section{Quantitative significance of style bacteriolytic activity in relation to nitrogen budget}

The data presented above allow some estimates to be made of the total bacteriolytic activity of the style, and of its potential ability to meet the nitrogen requirements of mussels of different sizes, provided that the total style protein in relation to body size is known.

The following regression (Seiderer et al., 1982) relates total style protein ( $\mathrm{mg}$ ) to Choromytilus

Table 1. Comparative data on the $\mathrm{C}: \mathrm{N}$ ratios of particulate or sub-particulate organic matter associated with kelp beds

\begin{tabular}{|lcl|}
\cline { 2 - 3 } $\begin{array}{c}\text { Particulate } \\
\text { organic matter }\end{array}$ & $\mathrm{C}: \mathrm{N}$ & \multicolumn{1}{c|}{ Source } \\
\hline Macrophytes & 15.6 & $\begin{array}{l}\text { Dieckmann (1978), } \\
\text { Koop et al. (1982) }\end{array}$ \\
Phytoplankton & 6.6 & $\begin{array}{l}\text { Bailey (pers. comm.) } \\
\text { Bishop et al. (1978) }\end{array}$ \\
Bacteria: Nutrient rich & 3.3 & Present study \\
Nutrient poor & 3.9 & Present study \\
\hline
\end{tabular}

meridionalis shell length $(\mathrm{mm}) ; \hat{\mathrm{Y}}=-3.47+0.16 \mathrm{X}(\mathrm{r}$ $=0.89, \mathrm{n}=20$ ). This can be used to relate the bacteriolytic activity of the proteins to the nitrogen requirements of the mussels in the following way. The protein concentrations of the style extracts were stan-

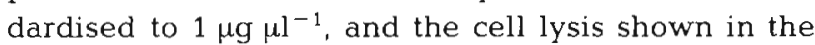
agarose plates (Fig. 1) was expressed in terms of the number of bacteria lysed per $\mu \mathrm{l}$ of extract in $45 \mathrm{~h}$. This can be converted to the amount of bacterial nitrogen made available ( $\mathrm{N}=$ protein/6.5) (Newell and Field, 1983) by a single crystalline style and related to the size of the mussel. The style turnover time for $C$. meridionalis is approximately $18 \mathrm{~h}$ (Seiderer et al., 1982); hence the final figure of maximum lytic capacity of the crystalline style has been expressed as $\mu \mathrm{g} \mathrm{N}$ made available in $1 \mathrm{~h}$. An estimate of the nitrogen requirements of different-sized mussels, using oxygen consumption data of Griffiths (1980), gave a mean value for respiration (R) of $74 \%$ of the absorbed ration (A).

Values for the oxygen consumption and its nitrogen equivalent, calculated using $\mathrm{C}: \mathrm{N}$ ratio of 4.74 (taken from Hawkins, 1983, for Mytilus edulis) and the absorbed ration at $1.35 \times$ the respiration are summarised in Table 2.

Table 2. Choromytilus meridionalis. Nitrogen requirements at different sizes (shell length, $\mathrm{mm}$ ). Data for nitrogen requirements recalculated as $\mu \mathrm{g} \mathrm{h}^{-1}$ from oxygen consumption $\left(\mu \mathrm{h} \mathrm{h}^{-1}\right)$ and absorbed ration (A) in Griffiths (1980) using a C: $N$ ratio of 4.74 (taken from Hawkins, 1983, for Mytilus edulis)

\begin{tabular}{|c|c|c|c|}
\hline \multirow{2}{*}{$\begin{array}{l}\text { Shell } \\
\text { length } \\
(\mathrm{mm})\end{array}$} & \multicolumn{2}{|c|}{ Respiration (R) } & \multirow{2}{*}{$\begin{array}{c}\text { Absorbed ration (A) } \\
\qquad\left(\mu g N \mathrm{~h}^{-1}\right)\end{array}$} \\
\hline & $\left(\mu 1 \mathrm{O}_{2} \mathrm{~h}^{-1}\right)$ & $\left(\mu g \mathrm{~N} \mathrm{~h}^{-1}\right)$ & \\
\hline 20 & 65 & 7.342 & 9.9 \\
\hline 40 & 220 & 24.873 & 33.6 \\
\hline 60 & 390 & 44.072 & 59.5 \\
\hline 80 & 670 & 75.717 & 102.2 \\
\hline 100 & 1000 & 113.228 & 152.8 \\
\hline
\end{tabular}

Data for filtration rate and bacterial yield from the water column for Choromytilus meridionalis of different sizes are summarised in Table 3. The filtration rates, recalculated from Griffiths (1980), are related to body size by the equation:Filtration rate $\left(\mathrm{l} \mathrm{h}^{-1}\right)=$ $6.44 \times 10^{3}$. (shell length, $\left.\mathrm{mm}\right)^{1.5764}$. Since the bacterial numbers in the water column were $4 \times 10^{5}$ cells ml ${ }^{-1}$

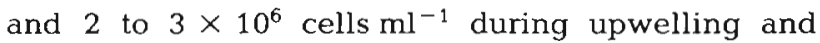
downwelling respectively (Linley, pers. comm.), the protein equivalents were 1.876 and $13.70 \mu \mathrm{g}$ protein $\mathrm{ml}^{-1}$ or 288.6 and $2,106.9 \mu \mathrm{g} \mathrm{N} \mathrm{l}^{-1}$, respectively, using a protein:nitrogen ratio of $6.5: 1$. This value has been used to estimate the gross nitrogen yield available by 
Table 3. Bacteria as a potential nitrogen resource for Choromytilus meridionalis. Filtration rates (I $\mathrm{h}^{-1}$ ) of mussels of different sizes (mm shell length) are from Griffiths (1980). Direct counts of bacterial numbers in the water column (bacteria ml-1 ${ }^{-1}$ (Linley, pers. comm.) were converted to bacterial protein $\left(\mu \mathrm{g}\right.$ protein $\left.\mathrm{ml}^{-1}\right)$ and thence to bacterial nitrogen $\left(\mu \mathrm{g} \mathrm{N}^{-1}\right)$. Filtration rates were used to convert the amount of bacterial nitrogen in the water column to the amount available to the mussel, assuming that only $57 \%$ of the bacteria are susceptible to lysis (Muir et al., in prep.) and that the retention efficiency of $0.5 \mu \mathrm{m}$ bacteria by $C$. meridionalis is $10 \%$ (Stuart, 1983). Maximum lytic activity ( $\mu \mathrm{g}$ made available $\mathrm{h}^{-1}$ ) was calculated from Fig. 3

\begin{tabular}{|c|c|c|c|c|c|}
\hline \multirow{2}{*}{$\begin{array}{l}\text { Shell length } \\
\qquad(\mathrm{mm})\end{array}$} & \multirow{2}{*}{$\begin{array}{l}\text { Filtration rate } \\
\qquad\left(1 \mathrm{~h}^{-1}\right)\end{array}$} & \multicolumn{2}{|c|}{ Bacterial $N$ from water } & \multirow{2}{*}{$\begin{array}{c}\text { N required by mussel } \\
\left(\mu g \mathrm{~N} \mathrm{~h}^{-1}\right)\end{array}$} & \multirow{2}{*}{$\begin{array}{c}\text { Maximum lysis } \\
\left(\mu \mathrm{g} \mathrm{N} \mathrm{h}^{-1}\right)\end{array}$} \\
\hline & & $\begin{array}{l}\text { Mininum } \\
\left(\mu g \mathrm{~N} \mathrm{~h}^{-1}\right)\end{array}$ & $\begin{array}{l}\text { Maximum } \\
\left(\mu \mathrm{g} \mathrm{h}^{-1}\right)\end{array}$ & & \\
\hline 20 & 0.724 & 12 & 87 & 10 & - \\
\hline 40 & 2.160 & 36 & 259 & 34 & 125 \\
\hline 60 & 4.092 & 67 & 491 & 60 & 261 \\
\hline 80 & 6.441 & 106 & 774 & 102 & 339 \\
\hline 100 & 9.156 & 151 & 1099 & 153 & 535 \\
\hline
\end{tabular}

filtration by each size class of mussel. However, as pointed out on p. 111 , only $57 \%$ of the water column bacteria were found to be susceptible to lysis. This and a retention efficiency of only $10 \%$ of $0.5 \mu \mathrm{m}$ bacteria by C. meridionalis (Stuart and Klumpp, 1984) were corrected for in the final calculation (Table 3).

From this it can be seen that the nitrogen yield potentially available from lysis of the susceptible component of bacteria in the water column shows a general correspondence with the estimated nitrogen requirements of each size class of mussel. In addition, the maximal lytic activity which could be achieved at high bacterial concentrations, and which is shown in the final column of Table 3 , is almost 4 times the nitrogen required by the mussels. It seems likely, therefore, that under upwelling conditions when the phytoplankton and macrophyte detritus loads are low, the nitrogen requirements of $C$. meridionalis can be met by the activity of the bacteriolytic enzymes of the style.

\section{CONCLUSIONS}

Lysozyme-like enzymes present in the style of the mussel Choromytilus meridionalis are capable of lysing approximately $57 \%$ of free-living bacteria in the water column adjacent to kelp beds. Estimates of the biomass of such bacteria through an upwelling-downwelling cycle and of the filtration rate of differentsized mussels suggest that free-living bacteria could meet the estimated nitrogen requirements of the mussels.

- Dr. A. J. Hawkins (Inst. for Marine Environmental Research, Plymouth) pointed out that a more direct method would be to use the O:N ratio. He has recently shown that in Mytilus edulis this ratio varies seasonally from 21 to 107 in well-fed mussels but is generally low in starved individuals. Use of the $\mathrm{O}: \mathrm{N}$ ratio for $M$. edulis yields values similar to those which were calculated in Table 2 from the C:N ratio
The bacteriolytic activity of the crystalline style is, however, in a remarkable and apparently adaptive equilibrium with the food resources available for exploitation in the water column during upwelling and downwelling conditions. When upwelling occurs, the water temperature is approximately $9^{\circ} \mathrm{C}$ and is poor in phytoplankton. Under these conditions, lysozyme-like activity is at its maximum and bacteria predominate as a nitrogen-rich exploitable food resource with a $C: N$ ratio of approximately $3.7: 1$. These phases of active upwelling are interspersed with an opposite flow of phytoplankton-rich warm surface water which occurs often within $24 \mathrm{~h}$ following an upwelling phase (Field et al., 1977). Under these conditions lysozyme-like activity of the crystalline style is at a minimum. Nutritional requirements are then met by the activity of the carbohydrases in the crystalline style which are capable of digesting the cell walls of phytoplankton and thus making protein available from the cell contents, as well as meeting the carbon requirements of the mussels from a detrital diet alone (Seiderer et al., 1982).

Whether these adaptive changes in the enzyme activity of the style are induced by the qualitative differences in particulate matter available in the water column, or by abrupt temperature changes associated with the upwelling-downwelling cycle is at present unknown. The rate of tumover of the style compared with the response time for the appearance of lysozymelike activity suggests, however, that specific enzymes may be incorporated into the style to meet relatively short-term changes in nutritional conditions in the water column near to kelp beds.

Acknowledgements. We thank Mr. Pete Fielding, Mr. Dave Muir and Mrs. Genevieve Wilson, all of the University of Cape Town. This work was mainly supported by funds from the Benguela Ecology Progranme of the South African National Committee for Oceanographic Research (F.T.R. and C.L.D.). A University of Cape Town Research Grant was 
provided for (F.T.R.), and a CSIR Post-graduate Bursary for (L.J.S.). Professor R. C. Newell is a Senior Research Fellow from the Royal Society.

\section{LITERATURE CITED}

Bishop, J. K. B., Ketten, D. R., Edmond, J. M. (1978). The chemistry, biology and vertical flux of particulate matter from the upper $400 \mathrm{~m}$ of the Cape Basin in the Southeast Atlantic Ocean. Deep Sea Res. 25: 1121-1161

Dieckmann, G. S. (1978). Aspects of growth and production of Laminaria pallida (Grev.) J. Ag off the Cape Peninsula. M. Sc. thesis, University of Cape Town

Fenchel, T. (1970). Studies on decomposition of organic detritus derived from the turtle grass Thalassia testudinum. Limnol. Oceanogr, 15: 14-20

Field, J. G., Griffiths, C. L., Linley, E. A., Carter, R. A., Zoutendyk, P. (1980). Upwelling in a near-shore marine ecosystem and its biological implications. Estuar. coast. mar. Sci. 11: 133-150

Field, J. G., Griffiths, C. L., Linley, E. A., Carter, R. A., Zoutendyk, P. (1981). Wind induced water movements in a Benguela kelp bed. In: Richards, F. A. (ed.) Coastal upwelling. American Geophysical Union, Washington D. C.

Field, J. G., Jarman, N., Dieckmann, G., Griffiths, C., Velimirov, B., Zoutendyk, P. (1977). Sun, waves, seaweed and lobsters: the dynamics of a west coast kelp-bed. S. Afr. J. Sci. $73: 7-10$

Fong, W. C., Mann, K. H. (1980). Role of gut flora in the transfer of amino acids through a marine food chain. Can. J. Fish. aquat. Sci. 37: 88-96

Foulds, J. B., Mann, K. H. (1978). Cellulose digestion in Mysis stenolepis and its ecological implications. Limnol Oceanogr. 23: 760-766

Griffiths, R. J. (1980). Filtration, respiration and assimilation in the black mussel Choromytilus meridionalis. Mar. Ecol. Prog. Ser. 3: 63-70

Groves, W. E., Davis, F. C., Sells, B. H. (1968). Spectrophotometric determination of microgram quantities of protein without nucleic acid interference. Anal. Biochem. 22: $195-210$

Hawkins, A. J. S. (1983). Metabolic strategy in the marine mussel, Mytilus edulis L. Ph. D. thesis, University of Exeter

Hutchings, L. (1981). The formation of plankton patches at the base of an upwelled plume in the Southern Benguela current. In: Richards, F. A. (ed.) Coastal upwelling. American Geophysical Union, Washington D. C.

Kirby-Smith, W. W. (1976). The detritus problem and the feeding and digestion of an estuarine organism. In: Wiley, M. (ed.) Estuarine processes, Vol. 1. Academic Press, New York, p. 469-479

Koop, K., Newell, R. C., Lucas, M. 1. (1982). Microbial regeneration of nutrients from the decomposition of macrophyte debris on the shore. Mar. Ecol. Prog. Ser. 9: 91-96

Kristensen, J. H. (1972). Carbohydrases of some marine invertebrates with notes on their food and on the natural occurrence of the carbohydrates studied. Mar. Biol. 14: $130-142$

Langton, R. W. (1977). Digestive rhythms in the mussel Mytilus edulis. Mar. Biol. 41: 53-58

Mann, K. H. (1982). Ecology of coastal waters - a systems approach. Studies in Ecology, Vol. 8. Blackwell Scientific Publications, Oxford

Mazure, H. G. F. (1977). Bacteria associated with kelp fronds in the Benguela upwelling system and their ecological importance. $\mathrm{Ph}$. D. thesis, University of Cape Town, South Africa

McHenery, J. G., Birkbeck, T. H. (1979). Lysozyme of the mussel, Mytilus edulis (L.). Mar Biol. Lett. 1: 111-119

McHenery, J. G., Birkbeck, T. H. (1982). Characterization of the lysozyme of Mytilus edulis (L.). Comp. Biochem. Physiol. 71B (4): 583-589

McHenery, J. G., Birkbeck, T H., Allen, J. A. (1979). The occurrence of lysozyme in marine bivalves. Comp. Biochem. Physiol. 63B: 25-28

Monar, I. (1972). Analysenautomat zur simultanen Mikrobestimmung von $\mathrm{C}, \mathrm{H}$ und $\mathrm{N}$. Mikrochim. Acta: 784-806

Moriarty, D. J. W. (1976). Quantitative studies on bacteria and algae in the food of the mullet Mugil cephalus L. and the prawn Matapenaeus bennettae (Racek and Dall). J. exp. mar. Biol. Ecol. 22: 131-143

Moriarty, D. J. W. (1977). Quantification of carbon, nitrogen, and bacterial biomass in the food of some penaeid prawns. Aust. J. mar. Freshwat. Res. 28: 113-118

Muir, D., Davis, C. L., Seiderer, L. J., Painting, S., Robb, F. T. Selective assimilation of bacteria by a marine mussel, Choromytilus meridionalis Krauss. (In prep.)

Newell, R. C. (1965). The role of detritus in the nutrition of two marine deposit feeders, the prosobranch Mydrobia ulvae and the bivalve Macoma balthica. Proc. Zool. Soc. Lond. $144: 25-45$

Newell, R. C. (1979). Biology of intertidal animals. Marine Ecological Surveys Ltd., Faversham, Kent, U. K.

Newell, R. C., Field, J. G. (1983). The contribution of bacteria and detritus to carbon and nitrogen flow in a benthic community. Mar. Biol. Lett. 4: 23-26

Prieur, D. (1981). Experimental studies of trophic relationships between marine bacteria and bivalve molluscs. Kieler Meeresforsch., Sonderh. 5: 376-383

Reiswig, H. M. (1971). Particle feeding in natural populations of three marine demosponges. Biol. Bull. mar. biol. Lab., Woods Hole 141: 568-591

Seiderer, L. J., Newell, R. C. (1979). Adjustment of the activity of $\alpha$-amylase extracted from the style of the black mussel Choromytilus meridionalis Krauss, in response to thermal acclimation. J. exp. mar. Biol. Ecol. 39: 79-86

Seiderer, L. J., Newell, R. C., Cook, P. A. (1982). Quantitative significance of style enzymes from two marine mussels (Choromytilus meridionalis Krauss and Perna perna Linnaeus) in relation to diet. Mar. Biol. Lett. 3: 257-271

Sieburth, J. McN. (1979). Sea microbes. Oxford University Press, New York

Sorokin, Y. I. (1973). Trophical role of bacteria in the ecosystem of the coral reef. Nature, Lond. 242: 415-417

Stuart, V., Lucas, M. I., Newell, R. C. (1981), Heterotrophic utilisation of particulate matter from the kelp Laminaria pallida. Mar. Ecol. Prog. Ser. 4: 337-348

Stuart, V. (1982). Absorbed ration, respiratory costs and resultant scope for growth in the mussel Aulacomya ater (Molina) fed on a diet of kelp detritus of different ages. Mar. Biol. Lett. 3: 289-306

Stuart, V., Field, J. G., Newell, R. C. (1982). Evidence for absorption of kelp detritus by the ribbed mussel Aulacomya ater using a new ${ }^{51} \mathrm{Cr}$ labelled microsphere technique. Mar. Ecol. Prog. Ser. 9: 263-271

Stuart, V., Klumpp, D. (1984). Evidence for food resource partitioning by kelp-bed filter feeders. Mar. Ecol. Prog. Ser., in press

Tenore, K. R. (1977a). Growth of Capitella capitata cultured on various levels of detritus derived from different sources. Limnol. Oceanogr. 22: 936-941 
Tenore, K. R. (1977b). Utilization of aged detritus from different sources by the polychaete Capitella capitata. Mar. Biol. 44: 51-55

Watson, S. W. (1978). Role of bacteria in an upwelling ecosystem. In: Boje, R., Tomczak, M. (ed.) Upwelling ecosystems. Springer Verlag, Berlin, Heidelberg, p. 139-154

Wetzel, R. L. (1976). Carbon resources of a benthic salt-marsh invertebrate Nassarius obsoletus Say (Mollusca: Nassariidae). In: Wiley, M. (ed.) Estuarine processes, Vol. 2. Academic Press, New York, p. 293-308

Yingst, Y I. (1976). The utilisation of organic matter in shallow marine sediments by an epibenthic deposit-feeding Holothurian. J. exp. mar. Biol. Ecol. 23: 55-69

This paper was submitted to the editor; it was accepted for printing on September 27, 1983 